\title{
The fossil record of the uppermost Maastrichtian Reptile Sandstone (Tremp Formation, northeastern Iberian Peninsula)
}

\author{
Alejandro BLANCO, Josep M. MÉNDEZ \& Josep MARMI*
}

Institut Català de Paleontologia "Miquel Crusafont"-Universitat Autònoma de Barcelona, C/ Escola Industrial, 23, 08201, Sabadell, Barcelona; alejandro.blanco@icp.cat; manuel.mendez@icp.cat; josep.marmi@icp.cat

* Corresponding author

Blanco, A., Méndez, J.M. \& Marmi, J. 2015. The fossil record of the uppermost Maastrichtian Reptile Sandstone (Tremp Formation, northeastern Iberian Peninsula). [El registro fósil de la Arenisca con reptiles del Maastrichtiense terminal (Formación Tremp, noreste de la Península Ibérica)]. Spanish Journal of Palaeontology, 30 (1), 147-160.

\begin{abstract}
Numerous localities with vertebrate remains, including dinosaurs (sauropods, ornithopods, theropods and ankylosaurs), crocodiles and turtles, are known in the Arén and Tremp Formations (Maastrichtian, northeastern Iberian Peninsula). This diverse fossil record is improving our understanding of the history of the latest Mesozoic faunas in Europe. A conspicuous 7 meter thick sandstone and/or microconglomerate level (the so called Reptile Sandstone) occurs near the top of the 'lower red unit' of the Tremp Formation, about 10 meters below the base of the 'Vallcebre limestone', which is Danian in age. Bone remains and ichnites are known in the Reptile Sandstone, and represent one of the youngest vertebrate records in the Maastrichtian of the Tremp Formation. New findings carried out in north Barcelona province complement the fossil assemblage of the Reptile Sandstone with turtle, crocodile, theropod and possible sauropod remains in addition to hadrosaurs.
\end{abstract}

Keywords: Late Maastrichtian, Tremp Formation, Reptile Sandstone.

\section{RESUMEN}

Numerosas localidades con restos de vertebrados, que incluyen dinosaurios (saurópodos, ornitópodos, terópodos y anquilosaurios), cocodrilos y tortugas, son conocidas en las Formaciones Arén y Tremp (Maastrichtiense, noreste de la Península Ibérica). Este diverso registro fósil está mejorando de forma notable nuestro conocimiento sobre la historia de las últimas faunas mesozoicas en Europa. Cerca del techo de la unidad roja inferior de la Formación Tremp, se encuentra una capa conspicua de areniscas y/o microconglomerados de unos siete metros de potencia, la cual se conoce como la Arenisca con reptiles. Su localización estratigráfica exacta es de unos 10 metros debajo de la base de la Caliza de Vallcebre, que es de edad Daniense. Los restos óseos y las icnitas son conocidos en la Arenisca con reptiles, los cuales representan uno de los registros más recientes de vertebrados de la sección maastrichtiense de la Formación Tremp. Nuevos hallazgos realizados en el norte de la provincia de Barcelona complementan el registro fósil de la Arenisca con reptiles con restos de tortugas, cocodrilos, terópodos y posibles saurópodos, además de hadrosaurios.

Palabras clave: Maastrichtiense superior, Formación Tremp, Arenisca con reptiles. 


\section{INTRODUCTION}

In the southern Pyrenees, marine-transitional to fully continental rocks of the Arén Sandstone and Tremp Formations (Maastrichtian-Thanetian) (Mey et al., 1968) have yielded a diverse vertebrate fauna with fishes, amphibians, squamates, turtles, crocodiles and dinosaurs (Riera et al., 2009; Marmi et al., 2012a). The Tremp Formation is widely exposed from the Vallcebre syncline (north Barcelona province, Catalonia, Spain) to the Huesca province (Aragón, Spain) and encompass the Cretaceous-Palaeogene boundary (K-Pg). Research works carried out over the last decades have considerably improved our knowledge on the diversity of some groups of dinosaurs that inhabited the Pyrenean region during the last 6 millions of years before the end-Cretaceous mass extinction (Riera et al., 2009; Vila et al., 2012, 2013). However, the diversity of other groups of vertebrates is partially known (Marmi et al., 2012a).

Within the Maastrichtian portion of the Tremp Formation, those localities closest to the K-Pg boundary are of great interest. The precise position of the K-Pg boundary is not fixed in the Tremp Formation. However, in the Vallcebre syncline, charophyte biostratigraphy (Feist \& Colombo, 1983) and magnetostratigraphy (Oms et al., 2007) suggest that the K-Pg boundary is located within a less than 10 meters thick pale red mudstone over a conspicuous sandstone and/or conglomerate level (the Reptile Sandstone of Masriera \& Ullastre, 1982) and beneath the Vallcebre limestone, which is of Danian age. The Reptile Sandstone crops out in numerous localities in the Vallcebre and Àger synclines and occurs within the magnetochron C29r (Galbrun et al., 1993; Oms et al., 2007). In the Pyrenees, some of the youngest records of dinosaurs have been reported in the Reptile Sandstone beds and consist of fragmentary bones (Masriera \& Ullastre, 1983; Ullastre \& Masriera, 1998; Pereda-Suberbiola et al., 2003) and footprints (Vila et al., 2013). Up to now, very few authors have paid attention on the description of vertebrate fossils from the Reptile Sandstone except PeredaSuberbiola et al. (2003), who described a distal epiphysis of a right femur assigned to an indeterminate hadrosaurid, and Vila et al. (2013), who reported hadrosaur footprints.

In this paper, new vertebrate remains from the Reptile Sandstone exposed in several localities of the Berguedà region (north Barcelona province) are described. In addition, their relevance to the uppermost Maastrichtian fossil record of the Tremp Formation is discussed.

\section{GEOLOGICAL SETTING}

The Tremp Formation (south-central and southeastern Pyrenees) (Mey et al., 1968) consists of Maastrichtian to
Thanetian materials deposited in an E-W foreland trough connected to the Atlantic Ocean, which was close to the boundary between the Iberian and European plates. It is also informally known as 'Garumnian' (Leymerie, 1862). The Tremp Formation sediments were deposited following a marine regression that began near the CampanianMaastrichtian transition (Oms et al., 2007 and references therein). After the uplift of the Pyrenean range, these deposits were separated into four synclines: Vallcebre, Coll de Nargó, Tremp and Àger from the east to west. The Tremp Formation was divided into four lithologic units by Rosell et al. (2001), which are from the base to the top: i) a transitional 'grey unit' (marls, coals, limestones, and sandstones), ii) a fluvial 'lower red unit' (mudstones, sandstones, oncoids, and palaeosols), iii) the lacustrine 'Vallcebre limestone' and laterally equivalent strata and, iv) a fluvial 'upper red unit' (mudstones, sandstones, conglomerates and limestones). According to charophyte biostratigraphy (Feist \& Colombo, 1983) and magnetostratigraphy (Oms et al., 2007), the two former units are Maastrichtian in age whereas the two later are Palaeocene.

The Reptile Sandstone, $7 \mathrm{~m}$ thick, occurs near the top of the 'lower red unit', about 7-10 m below the base of the Danian 'Vallcebre limestone' (Figs 1b-c). The Reptile Sandstone (Facies F10 in Oms et al., 2007) is composed of texturally and lithologically mature sediments (i.e., coarse-grained sandstones and microconglomerates rich in feldspars) displaying medium and large-scale cross-bedding (Fig. 2). These features, together with the lenticular crossbedded sandstones, the scarce mudstone interbeds and the absence of fining-up sequences and lateral accretion surfaces suggest deposition on braided streams under high-energy hydric regime (Oms et al., 2007). The Reptile Sandstone represents a period of high-energy flow in the basin and marks a change in the sedimentation regime from a previous muddy flood plain to a sandy braidplain. In the southern Pyrenees, this facies can be traced all over the Pedraforca thrust sheet (Oms et al., 2007) and in the Àger syncline, where it is eight meters thicker (Astibia et al., 2012). The Reptile Sandstone can be correlated with similar French Galante and Fleurie sandstone units and in all cases provenance is from the south and southwest extant massifs of Sardinia (Westphal \& Durand, 1990) and Ebro (Masriera \& Ullastre, 1982).

In the Vallcebre syncline, Feist \& Colombo (1983) located the K-Pg boundary in the mudstone separating the Reptile Sandstone and the base of the 'Vallcebre limestone', at the last occurrence of non-reworked Peckichara sertulata. Oms et al. (2007) found a strong correlation between polarities inferred from the Vallcebre section and the magnetic polarity time scale of Cande \& Kent (1995), from C32n.1n to C29r magnetochrons. Accordingly, these authors inferred a constant sediment accumulation rate of $77 \mathrm{~m} / \mathrm{Ma}$ through most of the 
Maastrichtian section in the Vallcebre syncline. Assuming this value, the Reptile Sandstone deposited between 130 and 220 ka before the K-Pg boundary.

\section{MATERIALS AND METHODS}

In October-November 2012 and April-June 2013, we conducted prospecting works in several localities at the north Barcelona province (localities 1 to 4 in Fig. 1a). Bone remains were collected from several exposures of the Reptile Sandstone. They consisted of bone fragments attributed to dinosaurs, partial, isolated plates belonging to turtles and a crocodile tooth. The material was restored by technicians from the Institut Català de Paleontologia Miquel Crusafont. Specimens preserving some diagnostic features were described and compared with published material from the Maastrichtian of southern Pyrenees. Unpublished specimens housed at the Museu Municipal de Berga from El Torrent del Jou (locality 5 in Fig. 1a) were also described and compared. All of them were photographed with digital camera and details were photographed under Leica EZ4D stereomicroscope integrating digital camera. Measurements were made on the pictures using the freeware ImageJ v. $1.40 \mathrm{~g}$ (Rasband, 1997-2008). The distal fragment of an hadrosaur femur reported by Pereda-Suberbiola et al. (2003) from Peguera (locality 6 in Fig. 1a) and footprints reported by Vila et al. (2013) from Cingles del Boixader (locality 7 in Fig. 1a) were not described in the present work. However, these specimens were taken into account in order to complete the database of the fossil record of the Reptile Sandstone. Studied material is stored in the collections of the Institut Català de Paleontologia Miquel Crusafont and Museu Municipal de Berga.

\section{GENERAL COMMENTS ON TAPHONOMY}

Vertebrate fossils are usually isolated and sparse through the Reptile Sandstone. Fossils occurred in different horizons at the most extended exposures (e.g., locality 2, Cingles de Cal Ros, Fig. 1c), but in several cases they were found in detached rough stones at the base of Reptile Sandstone cliffs or in small exposures of the Reptile Sandstone. This made difficult a precise stratigraphic correlation between fossil-bearing horizons belonging to different exposures or localities of the Reptile Sandstone. On the other hand, the lithological composition of the Reptile Sandstone is heterogeneous ranging from sandstones to microconglomerates, with oncolite layers interbedded, indicating heterogeneity of sedimentary environments. In this sense, only a general description on the state of preservation of vertebrate fossils from the Reptile Sandstone and the implications on taphonomy is provided.

A total of 44 bone remains and a tooth from the Reptile Sandstone were documented in the present fieldwork and previous studies (e.g., Pereda-Suberbiola et al., 2003). Due to their fragmentary nature and bad preservation, many remains $(56 \%)$ were classified as indeterminate. However, the remaining samples reveal a diversity of elements including a crocodile tooth, turtle plates (plastron and carapace) and bones attributed to dinosaurs. Turtles and dinosaurs represent the $27 \%$ and $15 \%$ of the sample respectively. Remains attributed to dinosaurs consisted of one transverse apophysis of a vertebra and several appendicular bones (two partial ischia, one epiphysis and one diaphysis belonging to two femora and some undetermined diaphyses). Fossils mostly appeared in coarse matrices (i.e., microconglomerate) showing a wide range of sizes, from less than one centimeter fragments (Fig. 2a) to a partial hadrosaur femur $45 \mathrm{~cm}$ long (Figs 2g-h, 6). However, most bones consisted of small sized fragments (74\% of the sample was less than $3 \mathrm{~cm}^{2}$ ) with clear evidence of weathering and abrasion (Figs 2b, d, f-h). Largest bones were heavily damaged with the medullar cavity sometimes infilled by the same sediment than the matrix (Figs 2h, 6). Some bones were covered by oncoids (Fig. 2c). All these evidence suggest that, as a rule, bone remains from the Reptile Sandstone were probably largely exposed and transported far away before their burial. This is consistent with sedimentology, which indicates deposition under a high-energy hydric regime (Oms et al., 2007). The only autochthonous remains of the Reptile Sandstone correspond to hadrosaur tracks (Hadrosauropodus) from the Cingles de Boixader locality (Fig. 1, Vila et al., 2013).

\section{SYSTEMATIC PALAEONTOLOGY}

\author{
Order CHELONII Latreille, 1800 \\ Chelonii indet.
}

(Figs 3a-d)

Material. IPS-81874, IPS-81875.

Locality. Cingles de Cal Ros (Cercs, Barcelona).

Description. Both specimens consist of fragments of turtle plastrons. IPS-81874 (Fig. 3a) probably corresponds to a left side fragment of a plastron including the bridge and the inguinal notch. It measures $11 \mathrm{~cm}$ long and $5.8 \mathrm{~cm}$ wide. The inguinal notch opening is slightly obtuse $\left(95.3^{\circ}\right)$. 


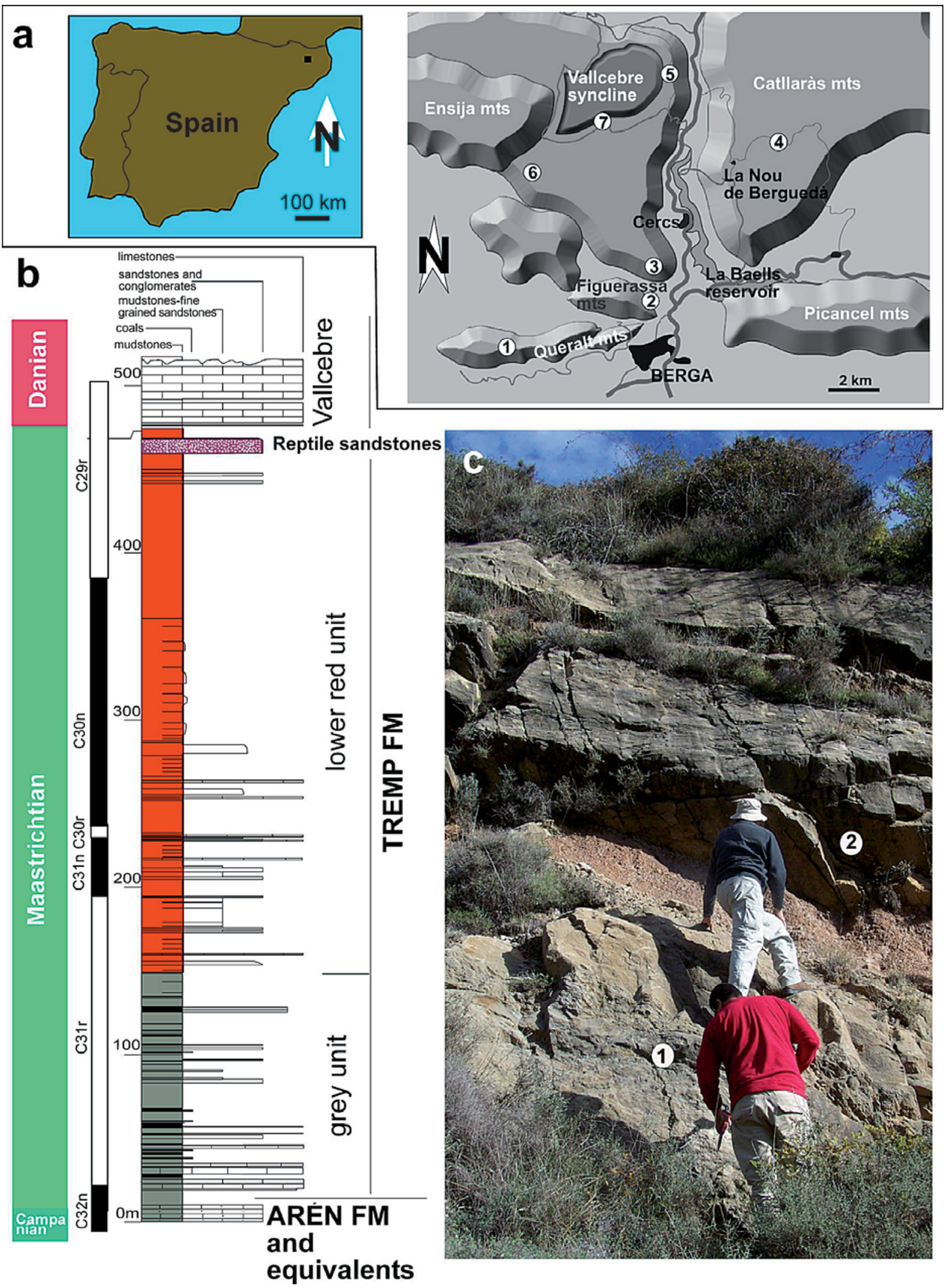

Figure 1. Geographical and geological setting of the studied area. a) Geographical location of the Reptile Sandstone outcrops where studied fossils were found: 1, El Portet; 2, Cingles de Cal Ros; 3, Tossal de la Guàrdia; 4, Cingles de la Creueta; 5, Torrent del Jou; 6, Peguera; 7, Cingles de Boixader. b) Synthetic section of the Tremp Formation from the Vallcebre syncline showing the location of the Reptile Sandstone (modified from Vila et al., 2005). c) Picture of the Reptile Sandstone outcropping at the Cingles de Cal Ros locality showing the horizons where two isolated bone remains were found: 1 , small bone fragment from an oncoid level (see Fig. 2a); 2, fragment of an hadrosaur femur (see Fig. 6). 

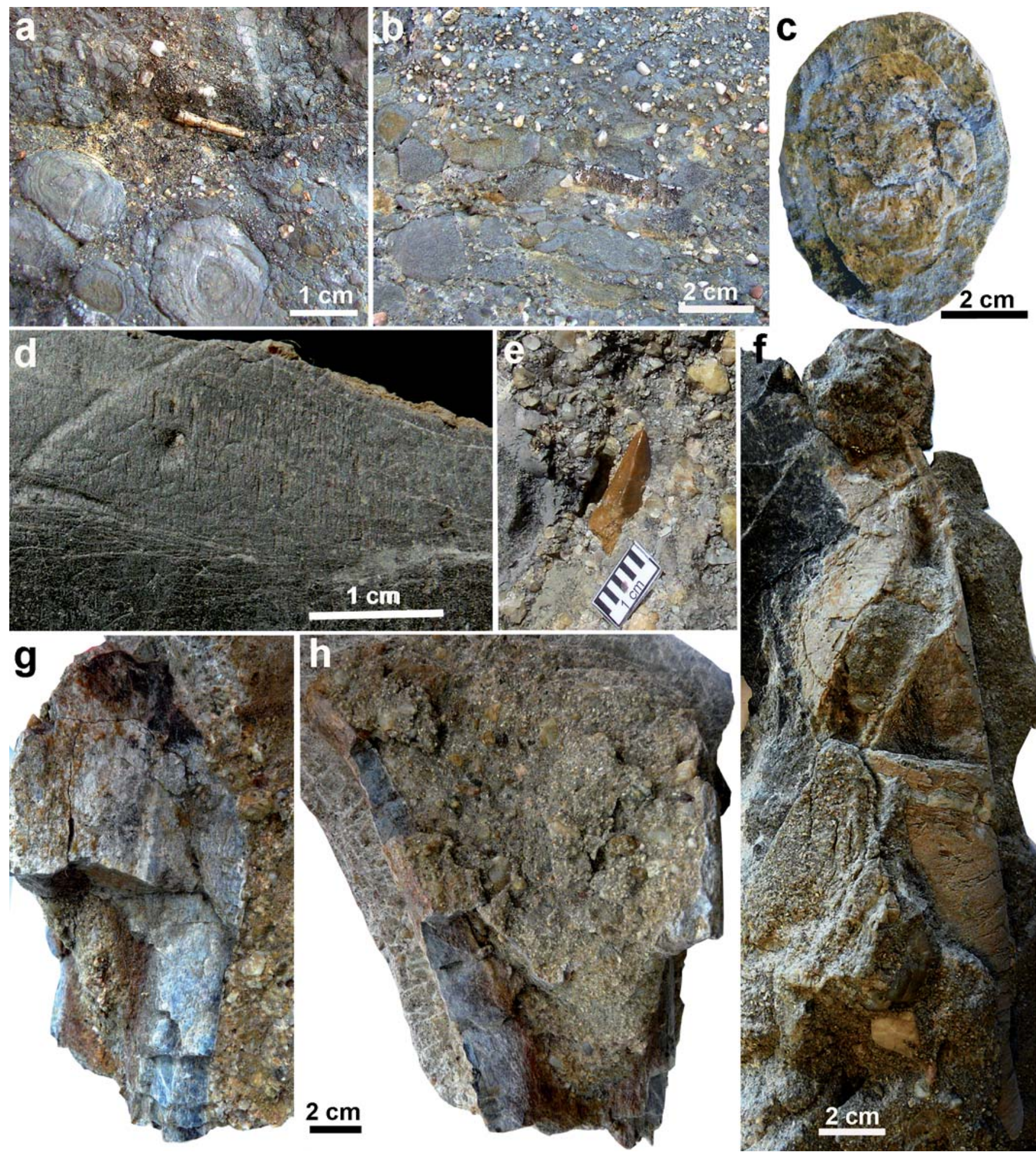

Figure 2. Examples of preservation in fossils from the Reptile Sandstone. a) Tiny bone in coarse-grained siliciclastic hybrid arenites rich in feldspars including oncoids. b) Section of a turtle plate in the transition from conglomerates to sandstones. c) Section of a bone covered by an oncoid. d) Detail of a turtle plate (see Fig. 3e for details) showing marks of abrasion. e) Crocodyle tooth (see Fig. 4 for details) within a microconglomerate matrix (scale equals $1 \mathrm{~cm}$ ). f) Elongated bone showing clear evidence of weathering and abrasion. g) Fragment of an hadrosaur femur (see Fig. 6 for details) included in a microconglomerate matrix. h) Another view of the same specimen showing the medullar cavity infilled by microconglomerate. 
IPS-81875 (Figs 3b-d) is flat and trapezoid in shape. It might correspond to a hyoplastron or hypoplastron based on the straight edge, which is interpreted as the hyohypoplastron suture, and the absence of pelvic girdle scar marks in the inner side. The edge opposite to the hyohypoplastron suture is strongly weathered. The bone is wider $(5.5 \mathrm{~cm})$ than longer $(4.6 \mathrm{~cm})$ and slender in section $(0.4 \mathrm{~cm})$.

Infraorder PLEURODIRA Cope, 1864

Family Bothremydidae Baur, 1891

Bothremydidae indet. (Figs 3e-f)

\section{Material. IPS-81876.}

Locality. Cingles de Cal Ros (Cercs, Barcelona).

Description. It corresponds to the first right peripheral plate of a turtle carapace (Fig. 3e). It is trapezoid in shape and measures $7.9 \mathrm{~cm}$ long and $5.5 \mathrm{~cm}$ wide. The anterior edge is longer $(5.2 \mathrm{~cm})$ than the posterior $(3.1 \mathrm{~cm})$. The sulcus between marginals 1 and 2 and the first vertebral scute is almost straight and not reaches the suture between peripheral 1 and costal 1 . The sulcus between first and second marginals is partially preserved. The surface is smooth and ornamented with very fine sulci, dichotomized and sometimes united forming small polygons (Fig. 3f).

Comparison. The well developed net consisting of dichotomic sulci suggests a highly vascularized shell bones. This feature has been used to recognize shell material of the Bothremydidae (e.g., Lapparent de Broin \& Murelaga, 1996; Murelaga \& Canudo, 2005). Elongated peripheral 1 with short posterior margin has been observed in bothremydids from the Campanian-Maastrichtian of the Pyrenees, such as Elochelys convenarum (Laurent et al., 2002), Foxemys mechinorum (Tong et al., 1998), Polysternon provinciale Matheron, 1869 (Gaffney et al., 2006) and P. isonae (Marmi et al., 2012b). In Elochelys and P. provinciale, the first pleural scute partially reaches the posterior end of the first peripheral, unlike the IPS-81876, Foxemys and $P$. isonae. In $P$. isonae, the marginal scutes cover almost all the surface or the first peripheral (Marmi et al., 2012b). However, in the studied specimen, marginals are shorter and the posterior third of the first peripheral is covered by the anterior edge of the first vertebral scute, as in $F$. mechinorum. The suture between the marginals and the first vertebral scute is almost straight in the IPS-81876 and F. mechinorum but it is curved in Polysternon species.

Order CROCODYLIFORMES Hay, 1930 (sensu Benton \& Clark, 1988)

Suborder EUSUCHIA Huxley, 1875
Unranked CROCODYLIA Gmelin, 1789 (sensu Benton \& Clark, 1988)

$$
\text { (Figs 4a-e) }
$$

Material. IPS-81877.

Locality. Cingles de la Creueta (La Nou del Berguedà, Barcelona).

Description. Conical tooth, with high crown, acute apex, and subcircular section (Fig. 4). It measures $1.71 \mathrm{~cm}$ in height and $0.8 \mathrm{~cm}$ wide and it is slightly labiolingually compressed (Fig. 4b). The tooth shows two well-developed mesodistal keels that converge at the apex. They are limited on the lingual side by two longitudinal grooves (Fig. 4c). The tooth is very slightly sloping towards the lingual side. The enamel is very smooth, without ornamentation, although fine ridges can be observed, under magnification, next to the mesodistal carinae, conforming a very soft false ziphodont dentition (Fig. 4d).

Comparison. This tooth lacks denticles and lateral compression, property of true ziphodont dentition. Based on the absence of these features, its inclusion within ziphosuchians can be rejected. The tooth morphology and size are similar to those described in CampanianMaastrichtian eusuchians from the Iberian Peninsula, such as Musturzabalsuchus and Allodaposuchus. The IPS-81877 shares with teeth attributed to these genera the following characters: conical shape with labiolingual compression and mesodistal keels or carinae limited by two prominent vertical grooves in the lingual side (Buscalioni et al., 1997, 2001; Delfino et al., 2008; Puértolas-Pascual et al., 2013). However, unlike IPS-81877, Musturzabalsuchus teeth show crown surfaces profusely ridged with the margins crenulated (Buscalioni et al., 1997, 1999). In Allodaposuchus, the enamel may be ridged (Delfino et al., 2008; Blanco et al., 2014), delicately wrinkled (Buscalioni et al., 2001) or smooth (Puértolas-Pascual et al., 2013). The species A. palustris (Blanco et al., 2014) has false ziphodont teeth but, unlike IPS-81877, their enamel is completely ridged. On this basis, the tooth herein described might correspond to a member of the genus Allodaposuchus.

Order SAURISCHIA Seeley, 1887

Suborder THEROPODA Marsh, 1881a

Theropoda indet.

(Figs 5a-b)

Material. IPS-81878.

Locality. Cingles de Cal Ros (Cercs, Barcelona). 

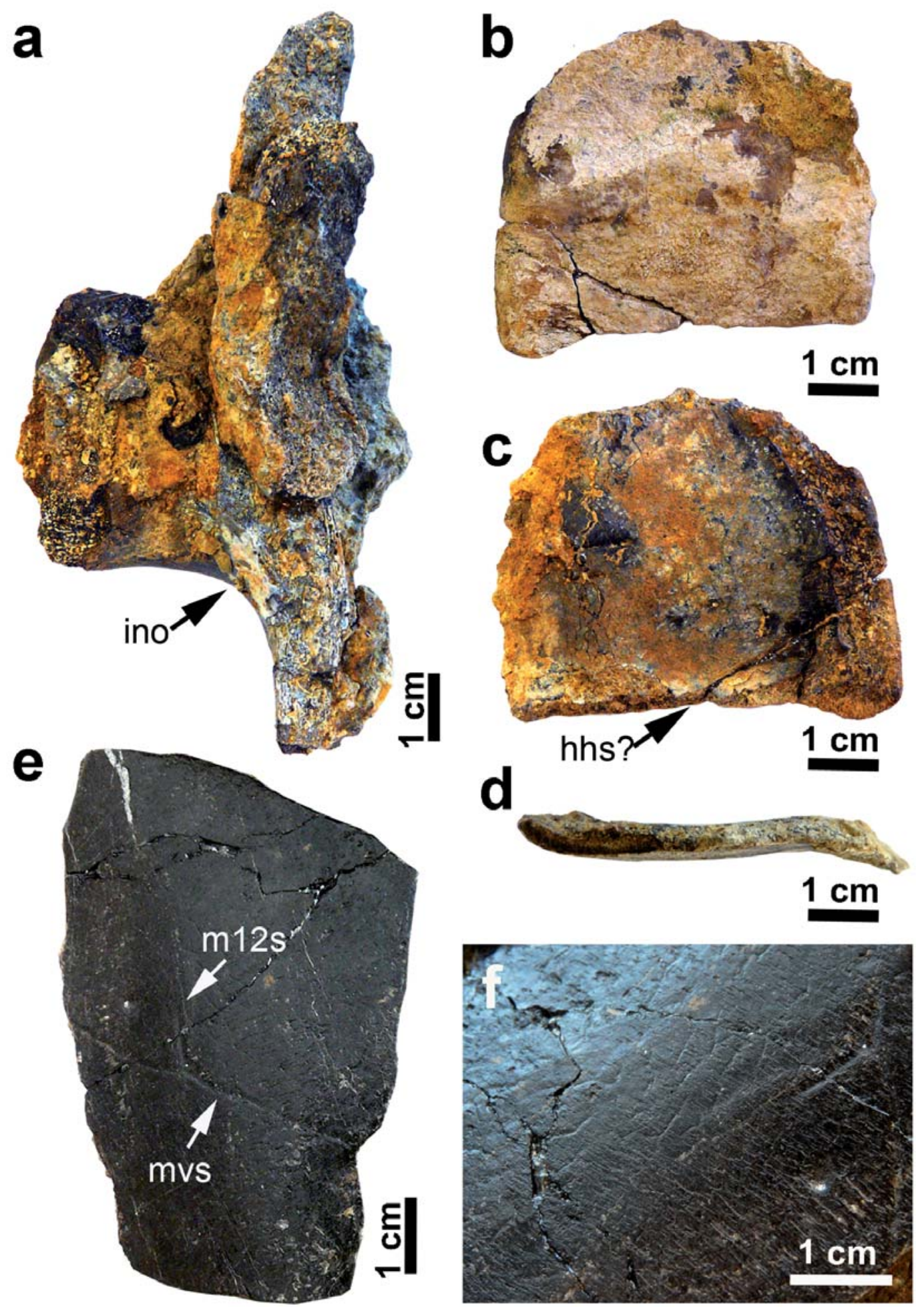

Figure 3. Turtle remains from the Cingles de Cal Ros. a) Fragment of a plastron showing the bridge and the inguinal notch (ino) (IPS-81874). b, c, d) Possible hyoplastron or hypoplastron (IPS-81875) in ventral, dorsal and transversal views, respectively, indicating the likely hyo-hypoplastron suture (hhs?). e) Peripheral plate of a bothremydid (IPS-81876) indicating the sulci between marginals 1 and $2(\mathrm{~m} 12 \mathrm{~s})$ and between the marginals and the first vertebral scute (mvs). f) Detail of the previous picture showing fine dichotomized sulci. 


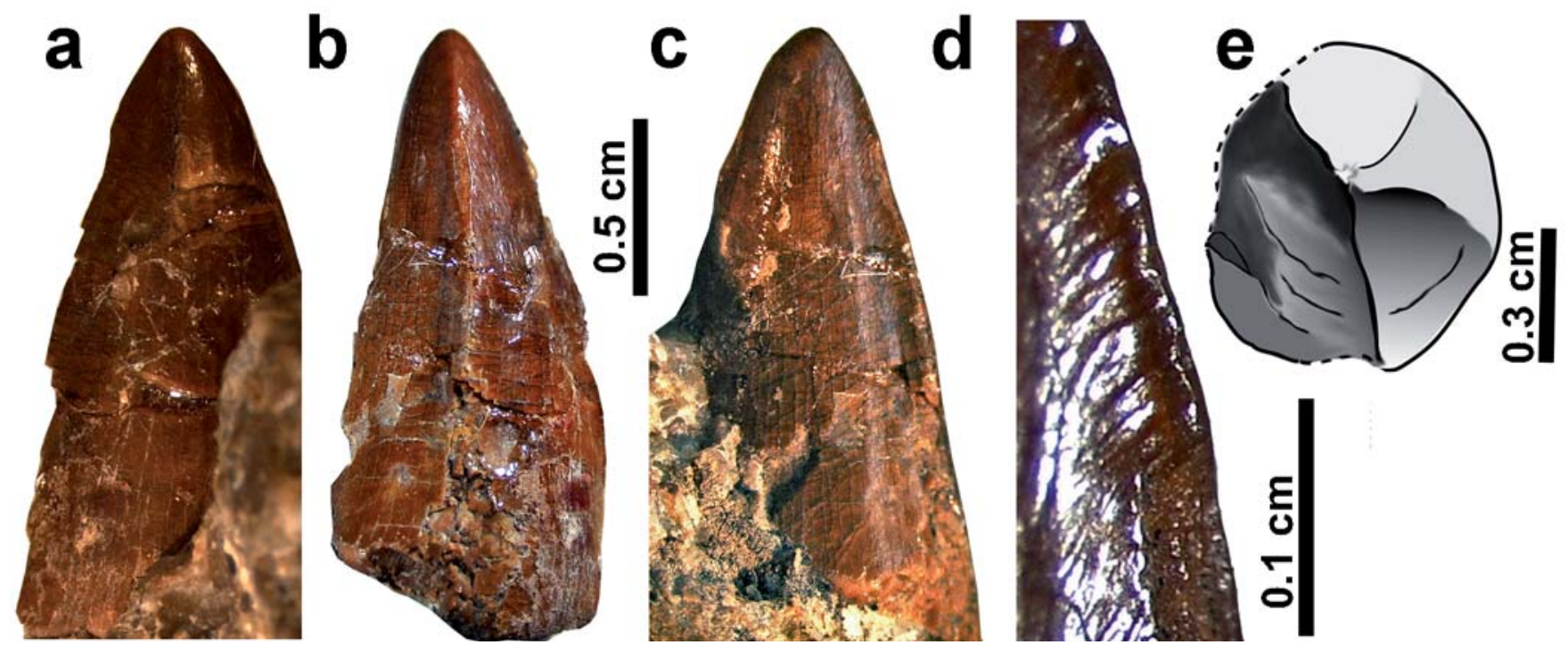

Figure 4. Crocodile tooth (IPS-81877) from Cingles de la Creueta. a) Labial view. b) Lateral view showing the carina. c) Lingual view showing longitudinal grooves. d) Detail of the lateral carina showing a very soft false ziphodont dentition. e) Drawing in apical view showing the outline of the section and carinae.

Description. It is a small long bone that only preserves the diaphysis (Fig. 5a). It measures $3.96 \mathrm{~cm}$ long and $0.49 \mathrm{~cm}$ wide. It has a subcircular section with a slim cortical bone $(0.015 \mathrm{~cm}$ in section) (Fig. $5 \mathrm{~b})$. The high vascularisation is patent in the broken end (Fig. 5b). There is a nutritional foramen in the medial part of the bone (Fig. 5a).

Comparison. The bone is difficult to classify due to it only preserves the diaphysis. However, the high vascularisation, the thin cortical bone, the elongated shape, the subcircular section and the presence of a nutritional foramen are shared with limb bones (e.g., ulna and humerus) of theropod dinosaurs. Although, the size of the bone is similar to those of small-sized theropods or birds, more diagnostic material is needed to confirm the presence of these dinosaurs in the Reptile Sandstone.

Order ORNITHISCHIA Seeley, 1887

Suborder ORNITHOPODA Marsh, 1881b

Family Hadrosauridae Cope, 1869

Hadrosauridae indet.

(Figs 6a-d)

Material. IPS-81879.

Locality. Cingles de Cal Ros (Cercs, Barcelona).

Description. The specimen consists of a robust long bone, broken at both ends. It measures $45 \mathrm{~cm}$ long and preserves the diaphysis, which measures $7.96 \mathrm{~cm}$ wide, and the basalmost part of the proximal epiphysis (Fig. 6a). The
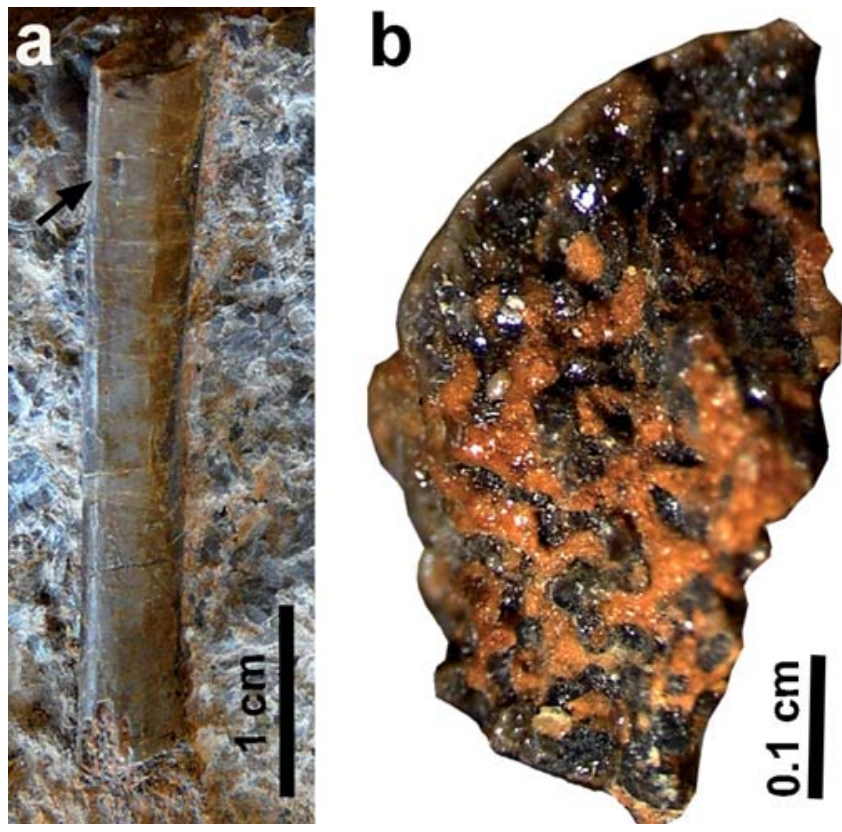

Figure 5. a) Diaphysis of a limb bone attributed to a theropod dinosaur (IPS-81878) from Cingles de Cal Ros. The nutritious foramen can be observed in the upper part of the bone (arrowed). b) Cross-section of IPS- 81878 showing a very thin cortical bone.

bone is interpreted as a right femur exposed in posterior view. The end of the proximal epiphysis is eroded, and no femur head is preserved. The base of the fourth trochanter can be observed, but it is not complete (Figs 6a-b). A wide, deep, longitudinal groove is present (Figs $6 a-b)$ from the 
forth trochanter to the distal end of the preserved diaphysis, and could be the posterior intercondylar groove in the distal epiphysis (Figs 6a-c). The distal epiphysis is eroded, and no description is possible for the distal condyles or the anterior intercondylar groove for the ilio-tibialis tendons.

Comparison. Although the bone is broken and eroded, the general shape is preserved, and it is different from that of a sauropod limb bone. On the other hand, the cortical bone is thicker $(1.32 \mathrm{~cm})$ (Fig. 6d) than it is expected in a theropod limb bone. Tyreophora dinosaurs are no present throughout the entire stratum. Thus, all these evidence and general description suggest that this specimen correspond to an hadrosaurid limb bone. Hadrosaur bone remains are known in the Reptile Sandstone level. Pereda-Suberbiola et al. (2003) cited a right distal femur and Vila et al. (2013) described hadrosaur footprints in the Reptile Sandstone outcropping at the neighboring localities of Peguera and Cingles del Boixader, respectively. The deep longitudinal groove below the forth trochanter of the specimen herein studied has been observed in other hadrosauroid femora from Maastrichtian sites in the Pyrenees such as MPZ2007/933 from Blasi (fig. 2f in Cruzado-Caballero et al., 2009), and an uncoded specimen from Magret (fig. 16.4s in Dalla-Vecchia et al., 2014a). This latter specimen is similar in outline and size to the partial femur IPS-81879
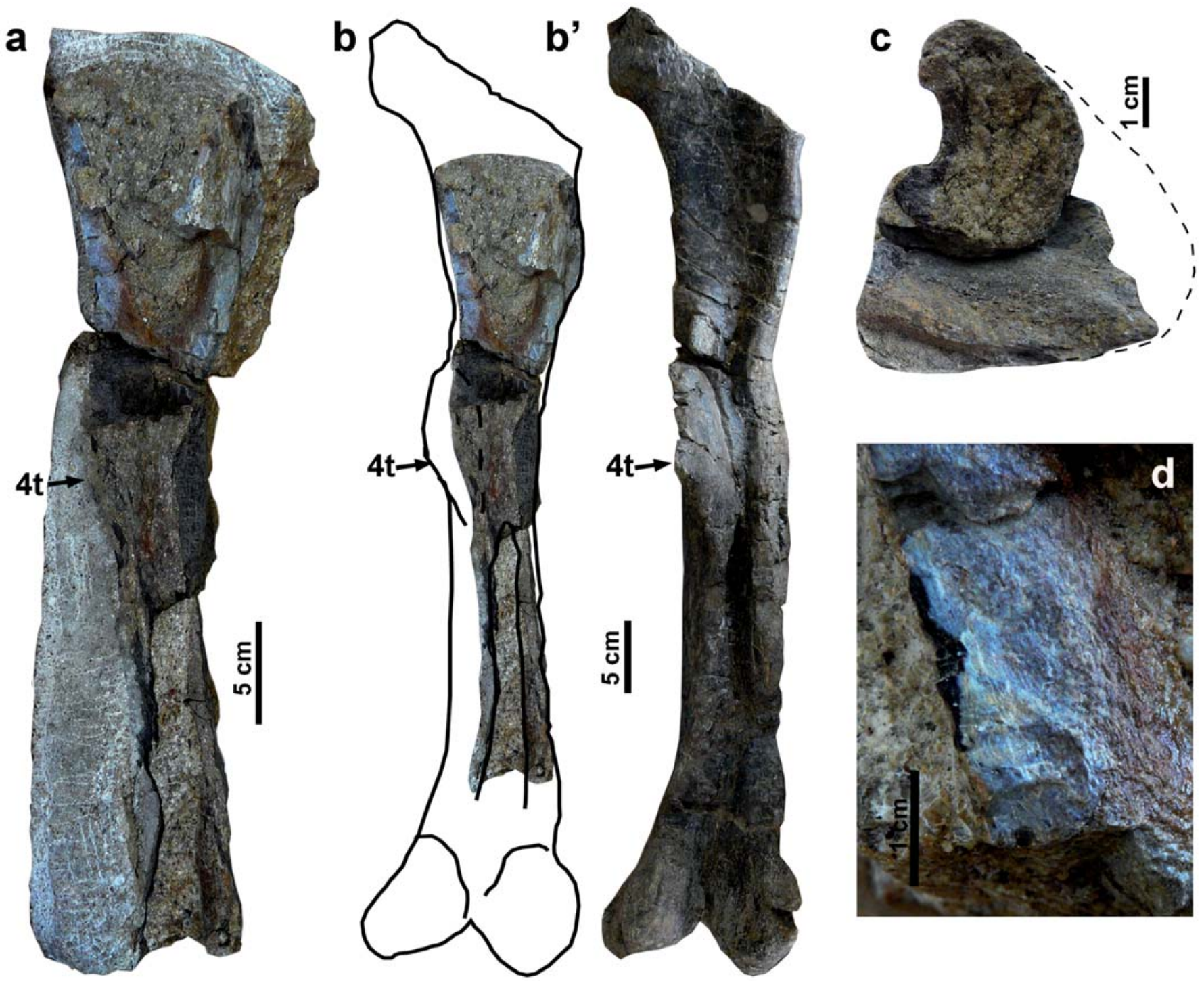

Figure 6. Partial hadrosaur femur (IPS-81879) from Cingles de Cal Ros. a) Posterior view of the fossil within the rock matrix. The base of the fourth throcanter $(4 \mathrm{t})$ is preserved and the deep longitudinal groove between the fourth throcanter and the condyles is clearly visible. b) Outline of an hadrosaur femur from the upper Maastrichtian locality of Magret (Tremp syncline), figured in b' and Dalla Vecchia et al. (2014a, fig. 16.4s), including IPS-81879 for its interpretation. c) Cross section of the distal end of IPS-81879 showing the outline of the longitudinal groove (left). d) Detail of the thick bone cortex in the proximal end of IPS-81879. 
(Fig. 6b-b'). The diaphysis of IPS-81879 is wider $(\sim 8 \mathrm{~cm})$ compared to the specimen reported by Pereda-Suberbiola et al. (2003) from Peguera, which is $3.2 \mathrm{~cm}$ wide.

Hadrosauridae indet.

$$
\text { (Figs 7a-i) }
$$

Material. MMB-1944, MMB-1476.

Locality. Torrent del Jou (Guardiola de Berguedà, Barcelona).

Description. The MMB-1944 (Figs 7a-e) is thin, elongated and slightly curved like the ischiadic shaft of an hadrosauroid ischium. It is $24.65 \mathrm{~cm}$ long and $2.6 \mathrm{~cm}$ wide. Its proximal end is wider in lateral view and measures 6.28 $\mathrm{cm}$ (Figs 7a-b). In dorsal-ventral views, the proximal end becomes narrow (Figs 7c-d). The section is elliptic at the distal end of the bone (Fig. 7e). The MMB-1476 (Figs 7f-i) is flat and trapezoidal. It measures $8.6 \mathrm{~cm}$ long and $6.64 \mathrm{~cm}$ wide. In its broken edge, it is almost circular in section and measures $3.3 \mathrm{~cm}$ (Fig. 7i). In one side, an ovoid, shallow concavity can be observed (Fig. $7 \mathrm{~g}$ ).

Comparison. MMB-1944 is very similar in shape to a partial lambeosaurine left ischium from Serrat del Corb in the Tremp syncline (fig. 15 in Prieto-Márquez et al., 2013). However, MMB-1944 cannot be assigned to Lambeosaurinae because it lacks the distal end. There, taxa included within Lambeosaurinae have a characteristic foot-like structure, expanding $90^{\circ}$ ventrally from the main structure of the shaft (Horner et al., 2004). MMB-1476 might represent a distal end of hadrosaur ischia. Its trapezoidal outline and the shallow depression resembles those of a lambeosaurine ischium (e.g., fig. 15 in Prieto-Márquez et al., 2013; fig. 16.8c in Dalla-Vecchia et al., 2014a).

\section{DISCUSSION}

The Reptile Sandstone records one of the youngest vertebrate fossil assemblages from the Late Cretaceous in Europe (Vila et al., 2013). These sandstone and/ or microconglomerate beds are included within the geomagnetic chron C29r (Oms et al., 2007) and, according to available data, deposited between 130 and $220 \mathrm{ka}$ before the K-Pg boundary in the Vallcebre syncline. Bilotte et al. (2010) described two hadrosaur fragments (maxilla and quadrate) from the uppermost Maastrichtian marine sediments of Larcan (Haute-Garonne, France), only one meter below the K-Pg boundary in this area. Thus, remains herein described would be slightly older than those from the French locality.
Turtles are reported through the Tremp Formation materials both in the coastal environments of the 'grey unit' and the fluvial environments of the 'lower red unit' (Marmi et al., 2012a). Up to now, the youngest turtle remains of the Tremp Formation were found in the Barranc de Torrebilles site (Isona i Conca Dellà, Lleida province), which also corresponds to C29r, being less than 300 ky older than the K-Pg boundary (Marmi et al., 2012b; Dalla Vecchia et al., 2013). Previously, Murelaga \& Canudo (2005) described isolated turtle plates, some of them assigned to bothremydids, from the Blasi and Rim sites (Arén and Serraduy, Huesca province), corresponding to the upper part of C30n or near the C30n-C29r transition (according to Oms \& Canudo, 2004). Several turtle bones were found in the Reptile Sandstone, representing $27 \%$ of the sample. These remains may be coeval or even younger than turtle remains from the Barranc de Torrebilles site. One specimen corresponds to a first peripheral of a bothremydid (Figs 3e-f) and it is clearly different (see description above) from Polysternon isonae from Barranc de Torrebilles, which was described by Marmi et al. (2012b). This suggests that several bothremydid forms inhabited fluvial environments from northwestern Iberia in the uppermost Maastrichtian.

Crocodile teeth and bones are also common throughout the whole Cretaceous portion of the Tremp Formation, but they seem more frequent in the fluvial environments of the 'lower red unit' (Marmi et al., 2012a). Uppermost Maastrichtian crocodile remains from the Tremp Formation were found at the Molí del Baró-1 site (Isona i Conca Dellà, Lleida province) and consist of isolated teeth (Marmi et al., 2012a). Recent magnetostratigraphic analyses suggest that this locality also falls within the C29r (Dalla Vecchia et al., 2014b). The study of the Molí del Baró-1 crocodile teeth is now in process and several morphotypes are preliminarly distinguished. However, IPS-81877 shows clear differences in shape, size and ornamentation compared to crocodrile tooth types from Molí del Baró-1. In fact, its morphology seems very close to the teeth described for genus Allodaposuchus, which is present in the Upper Cretaceous of the Iberian Peninsula and southern France (Buscalioni et al., 2001; PuértolasPascual et al., 2013). Up to now, the youngest remains correspond to Allodaposuchus subjuniperus (Puértolas et al., 2013) from the upper Maastrichtian of Serraduy del Pon (Huesca). Accordingly, IPS-81877 would represent one of the youngest records for this genus. On the other hand, the fossil record of theropods from the Tremp Formation is represented by scarce teeth, one locality with tracks, eggs, Prismatoolithidae-type eggshell fragments and rarely bones (Galobart et al., 2012; López-Martínez \& Vicens, 2012). The specimen IPS- 81878 would represent the first unequivocal theropod bone remain from the uppermost Maastrichtian of the Pyrenees.

The chronostratigraphic analysis of the ichnological record from the Tremp Formation revealed that all 

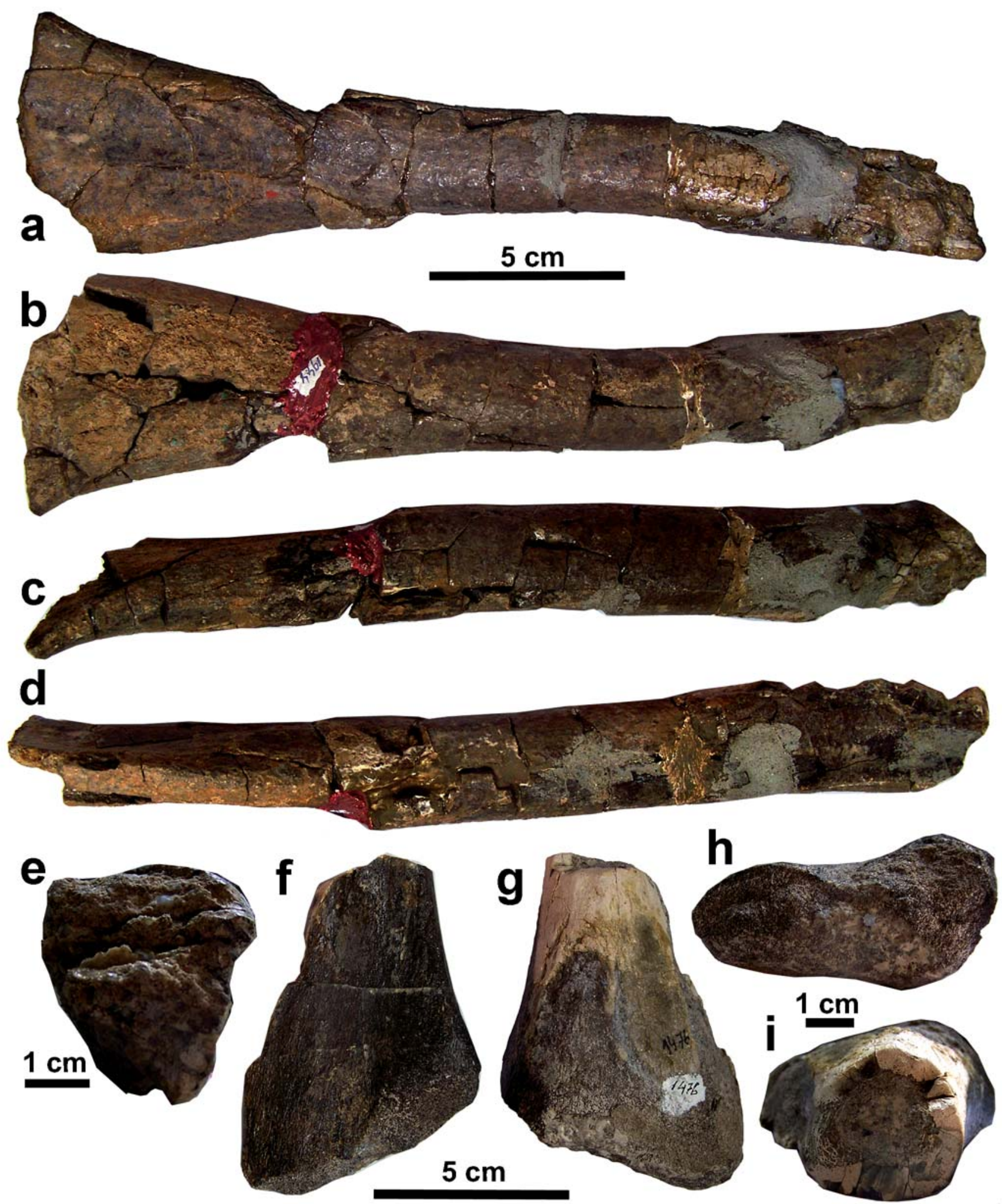

Figure 7. Ischiadic shaft of an hadrosauroid ischium (MMB-1944): a) Lateral view. b) Medial view. c) Ventral view. d) Dorsal view. e) Cross section. Possible foot-like expansion of a likely lambeosaurine right ischium (MMB-1476). f) Medial view. g) Lateral view. h) Dorsal view. i) Cross section. 
hadrosaur tracks occurred within the late Maastrichtian and the highest abundance was found in the last 300 thousand years of this time stage (Vila et al., 2013). This ichnological record includes hadrosaur tracks from the Reptile Sandstone exposed at Cingles de Boixader (locality 7 in fig. 1a, Vila et al., 2013). This finding demonstrates that hadrosaurs walked on channel muds during low water stage conditions in those braided stream environments (Vila et al., 2013). On the contrary, hadrosaur bone remains reported in the present study and Pereda-Suberbiola et al. (2003) showed clear evidence for allochthony. The partial femur IPS-81879 is similar to that reported by Dalla Vecchia et al. (2014a) from Magret locality (Tremp syncline), which falls within C31n, between 2.5 and 2.0 My older than the Reptile Sandstone.

Sauropod remains are also found in the latest Maastrichtian but they seem to be more frequent in the marine-to-continental transitional beds from the lower part of the succession (i.e., the 'grey unit' of the Tremp Formation) (Riera et al., 2009; Vila et al., 2013). LópezMartínez et al. (1999) reported the youngest sauropod footprints from the Pyrenees, at the Mas de Morull and Santa Maria de Meià sites (Lleida Province). These authors estimated an age of 200-350 ka before the end of chron C29r, indicating that the sites correspond approximately to the K-Pg boundary. However, Vila et al. (2013) considered both sites too poorly preserved to be of ichnotaxonomic significance. A sauropod bone was previously cited in the Reptile Sandstone outcropping at El Portet locality (Fig. 1a) by Ullastre \& Masriera (1998). These authors stated in their report that the material was identified by the French palaeontologist Phillip Taquet (Muséum National d'Histoire Naturelle de Paris) as a neural arch of a dorsal or sacral vertebra belonging to a sauropod. Unfortunately, the study of this specimen was not possible because it is not currently stored in any public research institution; it is probably lost or housed in a private collection.

\section{CONCLUSIONS}

The fossil record of the Reptile Sandstone does not show remarkable differences in taxonomic composition [at least at higher taxon level (i.e., from family to order)] compared to the remaining 'lower red unit' of the Tremp Formation. The vertebrate association of the Reptile Sandstone includes turtles (with members of Bothremydidae), possible Allodaposuchus crocodiles, possible sauropods, hadrosaurid ornithopods (with likely members of Lambeosaurinae) and possible theropods. Bone and tooth remains were strongly damaged by biostratinomic processes indicating long exposure and distant transport along braided stream systems. The only evidence of autochthony is found in hadrosaur footprints. Thus, ichnological record suggests that hadrosaurs inhabited braided river environments from the uppermost Maastrichtian Iberia. Vertebrate fossils from the Reptile Sandstone are among the youngest of the IberoArmorican domain (a large island that included emerged lands of Iberia and most of France in the westernmost part of the Upper Cretaceous southern European archipelago) (Dercourt et al., 2000). Reptile Sandstone beds probably deposited less than 220 ka before the K-Pg boundary.

\section{AKNOWLEDGEMENTS}

Fieldwork was authorized and funded by the Direcció General del Patrimoni Cultural (Departament de Cultura i Mitjans de Comunicació, Generalitat de Catalunya). A.B. was supported by an FI AGAUR grant from the DGR of the Generalitat de Catalunya (2013FI_B 01059). This research was also supported by the project CGL2011-30069-C02-01/ BTE (Ministerio de Economia y Competitividad, Gobierno de España). Authors acknowledge Julià Gonzàlez, Mattia Baiano, Pere Maillo and Alba Vicente for their assistance in the fieldwork. Authors are also very grateful to four anonymous reviewers and the associate editor (Dr. Julio Aguirre) for their constructive comments that improved considerably the earlier version of the manuscript.

\section{REFERENCES}

Astibia, H., López-Martínez, N., Elorza, J. \& Vicens, E. 2012. Increasing size and abundance of microbalites (oncoids) in the connection with the $\mathrm{K} / \mathrm{T}$ boundary in non-marine environments in the South Central Pyrenees. Geologica Acta, 10, 209-226.

Baur, G. 1891. Notes on some little known American fossil tortoises. Proceedings of the Academy of Natural Sciences of Philadelphia, 43, 411-430.

Benton, M.J. \& Clark J.M. 1988. Archosaur phylogeny and the relationships of Crocodylia. In: The phylogeny and classification of the tetrapods (ed. Benton M.J.). Clarendon Press, Oxford, 295-338.

Bilotte, M., Laurent, Y. \& Téodori, D. 2010. Restes d'hadrosaure dans le Crétacé terminal marin de Larcan (Petites Pyrénées, Haute-Garonne, France). Carnets de Géologie, 2, 1-9.

Blanco, A., Puértolas-Pascual, E., Marmi, J., Vila, B. \& Sellés, A.G. 2014. Allodaposuchus palustris sp. nov. from the upper Cretaceous of Fumanya (south-eastern Pyrenees, Iberian Peninsula): systematics, palaeoecology and palaeobiogeography of the enigmatic allodaposuchian crocodylians. PLoS ONE, 9, e115837 doi: 10.1371/journal. pone.0115837.

Buscalioni, A.D., Ortega, F. \& Vasse, D. 1997. New crocodiles (Eusuchia: Alligatoroidea) from the Upper Cretaceous of Southern Europe. Comptes Rendus de l'Académie des Sciencies de Paris, 325, 525-530. 
Buscalioni, A.D., Ortega, F. \& Vasse, D. 1999. The Upper Cretaceous crocodilian assemblage from Laño (Northcentral Spain): implications in the knowledge of the finicretaceous european faunas. Estudios del Museo de Ciéncias Naturales de Álava, 14, 213-233.

Buscalioni, A.D., Ortega, F., Weishampel, D.B. \& Jianu, C.M. 2001. A revision of the crocodyliform Allodaposuchus precedens from the Upper Cretaceous of the Hateg Basin, Romania. Its relevance in the phylogeny of eusuchia. Journal of Vertebrate Paleontology, 21, 74-86.

Cande, S.C. \& Kent, D. 1995. Revised calibration of the geomagnetic polarity time scale for the Late Cretaceous and Cenozoic. Journal of Geophysical Research, 100, 6093-6095.

Cope, E.D. 1864. On the limits and relations of the Raniformes. Proceedings of the Academy of Natural Sciences of Philadelphia, 16, 181-183.

Cope, E.D. 1869. Remarks on Eschrichtius polyporus, Hypsibema crassicauda, Hadrosaurus tripos and Polydectes biturgidus. Proceedings of the Academy of Natural Sciences of Philadelphia, 21, 192.

Cruzado-Caballero, P., Canudo, J.I. \& Ruiz-Omeñaca, J.I. 2009. Los fémures de Blasi (Arén, Huesca, Spain): una contribución a los hadrosauroideos europeos del Maastrichtiense superior. Actas de las IV Jornadas Internacionales sobre Paleontología de Dinosaurios y su Entorno, 197-205.

Dalla Vecchia, F.M., Riera, V., Oms, O., Dinarès-Turell, J., Gaete, R. \& Galobart, À. 2013. The last pterosaurs: first record from the uppermost Maastrichtian of the Tremp syncline (Northern Spain). Acta Geologica Sinica, 87, 1198-1227.

Dalla Vecchia, F.M., Gaete, R., Riera, V., Oms, O., PrietoMárquez, A., Vila, B., Garcia-Sellés, A. \& Galobart, À. 2014a. The hadrosauroid record in the Maastrichtian of Eastern Tremp Syncline (Northern Spain). In: Hadrosaurs: Proceeding of the International Hadrosaur Symposium at the Royal Tyrrell Museum (eds. Eberth, D. \& Evans, D.C.). Indiana University Press, Indiana, pp. 298-314.

Dalla Vecchia, F.M., Marmi, J., Blanco, A., Sellés, A.G., Fondevilla, V., Oms, O., Vicente, A., Martín-Closas, C. \& Galobart, À. 2014b. The late Maastrichtian land vertebrate site of Molí del Baró 1 (south-central Pyrenees, Spain). In: Field Trip Guide and Abstracts Book of the Reconstructing the Terrestrial end-Cretaceous Paleoenvironments in Europe (Tremp 2014) (eds. Marmi, J., Oms, O., Vila, B., Galobart, À., Estrada, R. \& Dinarès-Turell, J.). Paleontologia i Evolució, 7, 66.

Delfino, M., Codrea, V., Folie, A., Dica, P., Godefroit, P. \& Smith, T. 2008. A complete skull of Allodaposuchus precedens Nopcsa, 1928 (Eusuchia) and a reassessment of the morphology of the taxon based on the Romanian remains. Journal of Vertebrate Paleontology, 28, 111-122.

Dercourt, J., Gaetani, M., Vrielynck, B., Barrier, E., Biju-Duval, B., Brunet, M.F., Cadet, J.P., Crasquin, S. \& Sandulescu, M. 2000. Atlas Peri-Tethys, Palaeogeographical Maps. CCGM/CGMW, Paris.
Feist, M. \& Colombo, F. 1983. La limite Crétacé-Tertiaire dans le nord-est de l'Espagne, du point de vue des charophytes. Géologie Méditerranéenne, 10, 303-326.

Galbrun, B., Feist, M., Colombo, F., Rocchia, R. \& Tambareau, Y. 1993. Magnetostratigraphy and biostratigraphy of Cretaceous-Tertiary continental deposits, Àger basin, province of Lérida, Spain. Palaeogeography, Palaeoclimatology, Palaeoecology, 102, 41-52.

Galobart, À., Canudo, J.I., Oms, O., Vila, B., CruzadoCaballero, P., Riera, V., Gaete, R., Dalla Vecchia, F.M., Marmi, J. \& Sellés, A.G. 2012. The last dinosaurs of Europe: clade-specific heterogeneity in the dinosaur record of the southern Pyrenees. In: $10^{\text {th }}$ Annual Meeting of the European Association of Vertebrate Palaeontologists (eds. Royo-Torres, R., Gascó, F. \& Alcalá, L.). ¡Fundamental!, $20,85-88$

Gaffney, E.S., Tong, H. \& Meylan, P.A. 2006. Evolution of the side-necked turtles: the families Bothremydidae, Euraxemydidae, and Araripemydidae. Bulletin of the American Museum of Natural History, 300, 1-700.

Gmelin, J.F. 1789. Regnum animale. In: Caroli a Linne Systema Naturae per regna tri naturae, secundum classes, ordines, genera, species, cum characteribus, differentiis, synonymis, locis (ed. Beer, G.E.). Leipzig, 1(3), 1033-1516.

Hay O.P. 1930. Second bibliography and catalogue of the fossil vertebrata of North America. Carnegie Inst Wash Publication.

Horner, J.R., Weishampel, D.B. \& Forster, C.A. 2004. Hadrosauridae. In: The Dinosauria, Second Edition (eds. Weishampel, D.B., Dodson, P.D. \& Osmolska, H.). University of California Press, California, 438-463.

Huxley, T.H. 1875. On Stagonolepis robertsoni, and on the evolution of the Crocodilia. Quarterly Journal of the Geological Society of London, 31, 423-438.

Lapparent de Broin, F. de \& Murelaga, X. 1996. Une nouvelle faune de chéloniens dans le Crétacé supérieur européen. Comptes Rendus de l'Académie des Sciences, Paris, 323, 729-735.

Latreille, P.A. 1800. Histoire naturelle des salamandres de France. Villier, Paris.

Laurent, Y., Tong, H. \& Claude, J. 2002. New side-necked turtle (Pleurodira: Bothremydidae) from the Upper Maastrichtian of the Petites-Pyrénées (Haute-Garonne, France). Cretaceous Research, 23, 465-471.

Leymerie, A. 1862. Aperçu géognostique des Petites Pyrénées et particulièrment de la montagne d'Ausseing. Bulletin de la Société Geólogique de France, 19, 1091-1096.

López-Martínez, N. \& Vicens, E. 2012. A new peculiar dinosaur egg, Sankofa pyrenaica oogen. nov. oosp. nov. from the Upper Cretaceous coastal deposits of the Aren Formation, South Central Pyrenees, Lleida, Catalonia, Spain. Palaeontology, 55, 325-339.

López-Martínez, N., Fernández-Marrón, M.T. \& Valle, M.F. 1999. The succession of vertebrates and plants across the Cretaceous-Tertiary boundary in the Tremp Formation, Àger Valley (south-central Pyrenees, Spain). Geobios, $32,617-627$. 
Marmi, J., Luján, A.H., Dalla-Vecchia, F.M., Riera, V., Canudo, J.I., Vila, B., Puértolas, E., Vicente, A., Gaete, R., Galobart, À. \& Oms, O. 2012a. The fossil record of non-dinosaurian vertebrates from the latest Cretaceous of south-central and eastern Pyrenees. In: $10^{\text {th }}$ Annual Meeting of the European Association of Vertebrate Palaeontologists (eds. Royo-Torres, R., Gascó, F. \& Alcalá, L.). ¡Fundamental!, 20, 153-156.

Marmi, J., Luján, A.H., Riera, V., Gaete, R., Oms, O. \& Galobart, À. 2012b. The youngest species of Polysternon: a new bothremydid turtle from the uppermost Maastrichtian of the southern Pyrenees. Cretaceous Research, 35, 133-142.

Marsh, O.C. 1881a. Principal characters of American Jurassic dinosaurs Part V. American Journal of Science, ser. 3, 21, 417-423.

Marsh, O.C. 1881b. Principal characters of American Jurassic dinosaurs Part IV. Spinal cord, pelvis and limbs of Stegosaurus. American Journal of Science, ser. 3, 21, 167-170.

Masriera, A. \& Ullastre, J. 1982. Hipótesis y problemas acerca del origen de las asociaciones de minerals pesados del Senoniense del Pirineo Catalán. Cuadernos de Geología Ibérica, 8, 949-963.

Masriera, A. \& Ullastre, J. 1983. Essai de synthèse stratigraphique des couches continentales de la fin du Crétacé des Pyrénées Catalanes (NE de l'Espagne). Géologie Méditerranéenne, 10, 283-290.

Matheron, P. 1869. Notice sur les reptiles fossiles des dépots fluvio-lacustrines crétacés du bassin à lignite de Fuveau. Mémoires de l'Académie Impériale des Sciences, BellLettres et Arts de Marseille, 1-39.

Mey, P.H.W., Nagtegaal, P.J.C., Roberti, K.J.A. \& Hartelvelt, J.J.A. 1968. Lithostratigraphic sub-division of posthercynian deposits in the south central Pyrenees, Spain. Leidse Geologische Mededelingen, 41, 221-228.

Murelaga, X. \& Canudo, J.I. 2005. Descripción de los restos de quelonios del Maastrichtiense superior de Arén y Serraduy (Huesca). Geogaceta, 38, 51-54.

Oms, O. \& Canudo, J.I. 2004. Datación magnetostratigráfica de los dinosaurios del Cretácico terminal (Maastrichtiense superior) de Arén (Huesca, Unidad Surpirenaica Central). Geotemas, 6, 51-54.

Oms, O., Dinarès-Turell, J., Vicens, E., Estrada, R., Vila, B., Galobart, À. \& Bravo, A.M. 2007. Integrated stratigraphy from the Vallcebre Basin (southeastern Pyrenees, Spain): new insights on the continental CretaceousTertiary transition in southern Europe. Palaeogeography, Palaeoclimatology, Palaeoecology, 255, 35-47.

Pereda-Suberbiola, X., Ruiz-Omeñaca, J.I., Ullastre, J. \& Masriera, A. 2003. Primera cita de un dinosaurio hadrosaurio en el Cretácico Superior del Prepirineo oriental (Peguera, provincia de Barcelona). Geogaceta, 34, 195-198.
Prieto-Márquez, A., Dalla Vecchia, F.M., Gaete, R. \& Galobart, A. 2013. Diversity, relationships, and biogeography of the lambeosaurine dinosaurs from the European archipelago, with description of the new aralosaurin Canardia garonnensis. PLoS ONE, 8, 7: e69835. doi:10.1371/ journal.pone.0069835

Puértolas-Pascual, E., Canudo, J.I. \& Moreno-Azanza, M. 2013. The eusuchian crocodylomorph Allodaposuchus subjuniperus sp. nov., a new species from the latest Cretaceous (upper Maastrichtian) of Spain. Historical Biology, doi:10.1080/08912963.2012.763034

Rasband, W. 1997-2008. ImageJ: Image processing and analysis in Java [version 1.40g]. http://rsb.info.nih.gov/ ij/index.html.

Riera, V., Oms, O., Gaete, R. \& Galobart, À. 2009. The end-Cretaceous dinosaur succession in Europe: the Tremp Basin record (Spain). Palaeogeography, Palaeoclimatology, Palaeoecology, 283, 160-171.

Rosell, J., Linares, R. \& Llompart, C. 2001. El 'Garumniense' prepirenaico. Revista de la Sociedad Geológica de España, 14, 47-56.

Seeley, H.G. 1887. On the classification of the fossil animal commonly called Dinosauria. Proceedings of the Royal Society of London, 43, 165-171.

Tong, H., Gaffney, E.S. \& Buffetaut, E. 1998. Foxemys, a new side-necked turtle (Bothremydidae: Pelomedusoides) from the Late Cretaceous of France. American Museum Novitates, 3251, 1-19.

Ullastre, J. \& Masriera, A. 1998. Nuevas aportaciones al conocimiento estratigráfico del Paleoceno continental del Pirineo catalán (España). Treballs del Museu de Geologia de Barcelona, 7, 95-128.

Vila, B., Oms, O. \& Galobart, À. 2005. Manus-only titanosaurid trackway from Fumanya (Maastrichtian, Pyrenees): further evidence for an underprint origin. Lethaia, 38, 211-218.

Vila, B., Galobart, À., Canudo, J.I., Le Loeuff, J., DinarèsTurell, J., Riera, V., Oms, O., Tortosa, T. \& Gaete, R. 2012. The diversity of sauropod dinosaurs and their first taxonomic succession form the latest Cretaceous of the southwestern Europe: clues to demise and extinction. Palaeogeography, Palaeoclimatology, Palaeoecology, 350-352, 19-38.

Vila, B., Oms, O., Fondevilla, V., Gaete, R., Galobart, À., Riera, V. \& Canudo, J.I. 2013. The latest succession of dinosaur tracksites in Europe: hadrosaur ichnology, track production and palaeoenvironments. PLOS ONE, 8, e72579, doi: 10.1371/journal.pone.0072579.

Westphal, M. \& Durand, J.P. 1990. Magnétostratigraphie des series continentales fluvio-lacustres du Crétacé supérieur dans le synclinal de l'Arc (region d'Aix-en-Provence, France). Bulletin de la Société Geólogique de France, 8, 609-620. 